\title{
European museum knowledge
}

\section{Peter Aronsson}

I was invited to write about the current state of the museological field, and my response is to take a European perspective, drawing on my recent experiences, leading a major panEuropean research project about national museums.

The creation of the grand modern collections of natural and cultural artefacts of European national museums were at the heart of the empirical revolution of epistemology in the eighteenth and nineteenth centuries. Collections born in the ancient regime as examples of the wonders of God and Nature were transformed to or replaced by systematic collections mapping the history of everything. Sequences, like Thomsen's Stone, Bronze and Iron Ages, seemed to reveal the Order of Things and were possible to exhibit in new museums (Aronsson \& Elgenius 2015).

Being at the heart of the new, modern representation of the world, museums became ideologically loaded and supplied a cultural fundament for secular, modernist and nationalistic world views. Hence a logic of culture is at the heart of the societal role of museums (Bennett 2006).

The creation of museology which followed upon the creation of a modern museum landscape can on the one hand be perceived as part of a professionalization of museum specific skills, beyond the original academic disciplines, and bring practices to order, conserve, educate, exhibit and communicate. On the other hand it provides meta-reflection to understand the dynamic role of museums in the making and reshaping of societies and world views into the remit of academic consideration and legitimization. The core institution of museology, Museum studies at Leicester in Britain is recently celebrating its 50 years anniversary and display both these dimensions of museology.

The proliferation of a specific critical perspective regarding museums is connected to the cultural constructivist turn in cultural sciences which became the new normal from the 1980s and onwards. The idea of the invention of traditions was paradigmatic for this turn, as well as a criticism of methodological nationalism and naive empiricism. For museum studies there has developed separate strands for the practical and affirmative management of museums on the one side, and a critical normative strand on the other. The latter has had the upper hand in academic and research oriented circles, as demonstrated by the success of the first international conference on Critical Heritage Studies in Gothenburg in 2012. The former, on the other hand, is in great demand from many museum institutions for teaching the practical, hands on skills, needed to run museums. Critical reflection as a tool for museum development seems to be a construction that is difficult to establish since there is constant demand from within institutions for positive examples and good news rather than critical enquiry to reshape museum work. 


\section{WITHIN A FIELD OF MEMORY POLITICS}

Every discipline in humanities and many in social sciences has added a field of enquiry that addresses issues of how the discipline itself interacts with society, a critical enquiry into how its knowledge production helps shaping society and culture. For me, the general terminology to describe these different strands is "uses of the past". Museums and the heritage field are among the most prominent, consequential and interesting formats regarding this strand of research. If well managed, they contribute to a culture of trust and creativity in society. If mismanaged or misused, the lack of trust or even the fostering of hatred contribute to social conflict instead of reconciliation.

This way of regarding museums and the heritage field came out of a large comparative European project, EuNaMus, where we focused the roles of National museums in the long term historical developments of European nations and states (EuNaMus homepage).

In later European projects, dealing with heritage, war and reconciliation, other segments of heritage, museums and culture has also been investigated. The Horizon funding framework has induced crossnational cooperation, multi-disciplinary approaches and an urge to interact between museums and the academy in the face of an increasing understanding of a European crisis, including severe austerity measures and tensions relating to migration, right wing populism and rising EU-scepticism in many parts of Europe. Cultural analyses are asked for in this framework programme to deal with tensions born out of European history, such as the world wars and nationalisms. In the context of a widening concept of sustainability, as in Agenda 2030, social, economic and climate sustainability has a growing attraction to legitimise the value also for museum studies. In a longer perspective, this tendency conforms to classical ways to legitimize museology:

1. Cultural policy as a rescue operation to secure a loss of heritage due to erosion and time often working as a stabilising force in times of rapid transformation (after the Napoleonic wars, the industrial transformation and urbanisation and so on)

2. Critical enquiry, relating to contemporary issues, but marking an explicit anti-affirmative standpoint in analogy with the idea of critical scientific investigation - in reality arguing affirmatively for less advantaged and forgotten minorities, aspects, and so on.

3. Science (or art) for its own sake - and here museology as a late-comer has had difficulties in relationship to say archaeology, where a mainstream position has been to focus on expanding the primary material without any regard to contemporary concerns.

A recent overview of contemporary European, museological projects following EuNaMus can be found in an online magazine of the TRACES project (Traces Journal \#02) and I will briefly describe what may be the four most important ones.

The MeLA project (European Museums in an Age of Migrations) was working in 2011-2015. The project investigated the role of museums in 21st century Europe, understanding the contemporary situation as an era of accelerated migration. The project was advising museums on how to meet challenges and opportunities to foster respect for diversity, support mobility and the development of European citizenry through 
shared visions of communal heritage across borders (MeLA project description).

The TRACES project (Transmitting Contentious Cultural Heritages with the Arts from Intervention to Co-Production) was active in 2016-2019. TRACES, like MeLa, was oriented towards contemporary practices and worked to transgress and develop new modes of interaction between academic research and artistic and societal practice, moving from intervention to co-production pushing ideas of outreach and impact one step forward (TRACES project homepage).

The CoHERE project (Critical Heritages: performing and representing identities in Europe) works in 2016-2019. The project aimed to identify, understand and valorise European heritages and their potential for developing communitarian identities. It addressed an intensifying EU Crisis through a study of relations between identities and representations of history (CoHERE project homepage).

Finally, the UNREST project (Unsettling Remembering and Social. Cohesion in Europe) is active 2016-2019. The project maps various strategies to deal with difficult heritage of the Holocaust and the world wars in excavations and museums. It works with the concept and innovative practices of "agonistic memory" to find productive ways to embrace political controversies and not give naive affirmation to official cosmopolitan narratives or populistic right wing ethnic revisions (UNREST project homepage).

These four recent initiatives are only a handful of all relevant pan-European projects taking place this decade. Little by little, the capacity to interact between the arts, museums and the academy is explored and expanded. I think that the EU funding programmes have been helpful to challenge academic research to interact more intensively with stakeholders outside the academy, but the incentive and capacity to bring the results to work are nevertheless scarce. The most pressing issue to work with now is the capacity to synthesize findings and make them valuable both to research, institutions and the public sphere. The scarcity of methods, funding and ambitions to do so needs to be acted on to make use of all these recent efforts and results.

To enhance the situation would call for reform both of research funders and cultural policy makers. There is a need to create funding for synthesizing efforts in the knowledge economy. Now too many valuable results are put onthe shelfand not reused as a foundationfor thenext level of research or policy actions. Secondly, cultural institutions need to enhance their capacity to use academic knowledge for their development and thirdly, participating in the wider knowledge economy should give merit also within academia.

This seems to me to be the current situation regarding research projects on museum issues on a European level. In the light of singular museum projects in the Nordic countries and the mentioned international projects it would be timely for an increase in Baltic and/ or Nordic cooperation on projects exploring the co-productive area in-between academy, museums, culture and creative industries.

\section{INTERNET SOURCES}

CoHERE project homepage: https://research.ncl. ac.uk/cohere/about/

EuNaMus homepage: www.eunamus.eu

MeLA project description: www.mela-project.polimi. it/upl/cms/attach/20150916/164249296_8862.pdf

TRACES project homepage: www.traces.polimi.it/ about/ 
MuSEOLOGICAL SHORTCUTS

160 Traces Journal \#02 (January 2017): www.traces.polimi. it/2017/02/15/issue-02-europe-and-contentiouscultural-heritage/

UNREST project homepage: www.unrest.eu

\section{LITERATURE}

Aronsson, Peter \& Gabriella Elgenius (eds.) 2015.

National Museums and Nation-building in

Europe 1750-2010. Mobilization and legitimacy,

continuity and change. London: Routledge.

Bennett, Tony 2006. "Exhibition, Difference and the Logic of Culture." In Ivan Karp et al. (eds.).

Museum frictions. Public cultures/global transforma-tions. Durham, N.C.: Duke University

Press, 46-69.

Peter Aronsson, Professor of History

peter.aronsson@lnu.se

Linnaeus University

SE-35195 Växjö, Sweden 